\title{
Assessment \\ of Observation Network and State of Exploration as to Groundwater Dynamics within Ukrainian Hydrogeological Province of Dnieper River
}

Abstract: In order to restart the state hydrogeological network and adhere it to European standards in the shortest possible terms, the following top-priority tasks shall be performed: an inventory of the observation stations, assessment of their representativeness, development of the concept for the monitoring system reformation, as well as creation of a single database with GIS-technologies. To solve the abovementioned tasks, we have carried out a geoinformation analyses concerning the locations of ground water monitoring stations within the largest hydrogeological structure in Ukraine (which is the water exchange basin of the Dnieper River). In the course of the study, a geodatabase has been created that includes digital cartographic layers of the topographic base, hydrogeological zoning under the geological structural, and water exchange principals as well as the surface and groundwater monitoring stations of different aquifers.

The obtained results establish the grounds for developing the concept and introduce a system of hydrogeological monitoring in Ukraine based on the geoinformation approach and integrated water resource management in the river basins.

Keywords: Hydrogeological monitoring, river basin model, geoinformation approach, observation points

\footnotetext{
* Ivano-Frankivsk National Technical University of Oil and Gas, Ivano-Frankivsk, Ukraine
} 


\section{Introduction}

Groundwater is a strategic natural resource and the most-dynamic component of the geological environment. Its activity is closely connected with the development and activation of hazardous exogenous geological processes, and it affects a number of ecological and economic problems such as the flooding of areas, maintenance of the optimal hydrogeological dynamics in the mining regions, land development, etc.

Nowadays in Ukraine, despite sufficient knowledge of its hydrogeological conditions) an extremely unfavorable and threatening situation has been created in connection with the systematic observation of the quantitative and qualitative characteristics of the underground water. The insufficient funding, outdated measuring equipment, suspension and abandonment of the observation wells, absence of a single database and coordinated interaction between the organizations subjected to monitoring, suspending the observations over the variability of the levels and chemical composition, and the loss of long-term observation data as a result render it impossible to make a reasonable prediction and take control of the groundwater [10]. In addition, the hydrogeological monitoring in Ukraine is carried out according to the administrative-territorial principle, whereas one of the main principles of the EU Water Framework Directive states an integrated water resource management in the river basins that envisages coordination of the water protection measures as to the surface and ground water belonging to the common ecological, hydrological, and hydrogeological systems [2]. These water exchange basins, whose sizes and boundaries are usually determined by the sizes and configuration of the river basins, should be considered as specific territorial systematic units while studying the underground hydrosphere that is closely connected with external factors that form the supply and discharge of groundwater [10].

\section{Conditions of Groundwater Dynamic Formation within Studied Territory}

The watershed basin of the Dnieper River, which is one of the largest rivers in Europe, has a total area of $511,000 \mathrm{~km}^{2}$ and is a trans-border system: $20 \%$ of its territory is located in the Russian Federation, 23\% - in Belarus, and 57\% within the boundaries of Ukraine (Fig. 1). The studied area occupies about half of Ukraine, stretches from north to south, and completely covers the northern part of the country, gradually narrowing southward.

The waters of the Dnieper River basin amount to about $80 \%$ of all water resources in Ukraine. The distribution of water resources in the Dnieper basin is very uneven. The upper part, which is the portion with the most water provided, receives $219,000 \mathrm{~m}^{3} /$ year of water per square kilometer in an average water year, and the 
available water supply decreases to $36,000 \mathrm{~m}^{3} /$ year of water per square kilometer in the lower part of the basin.

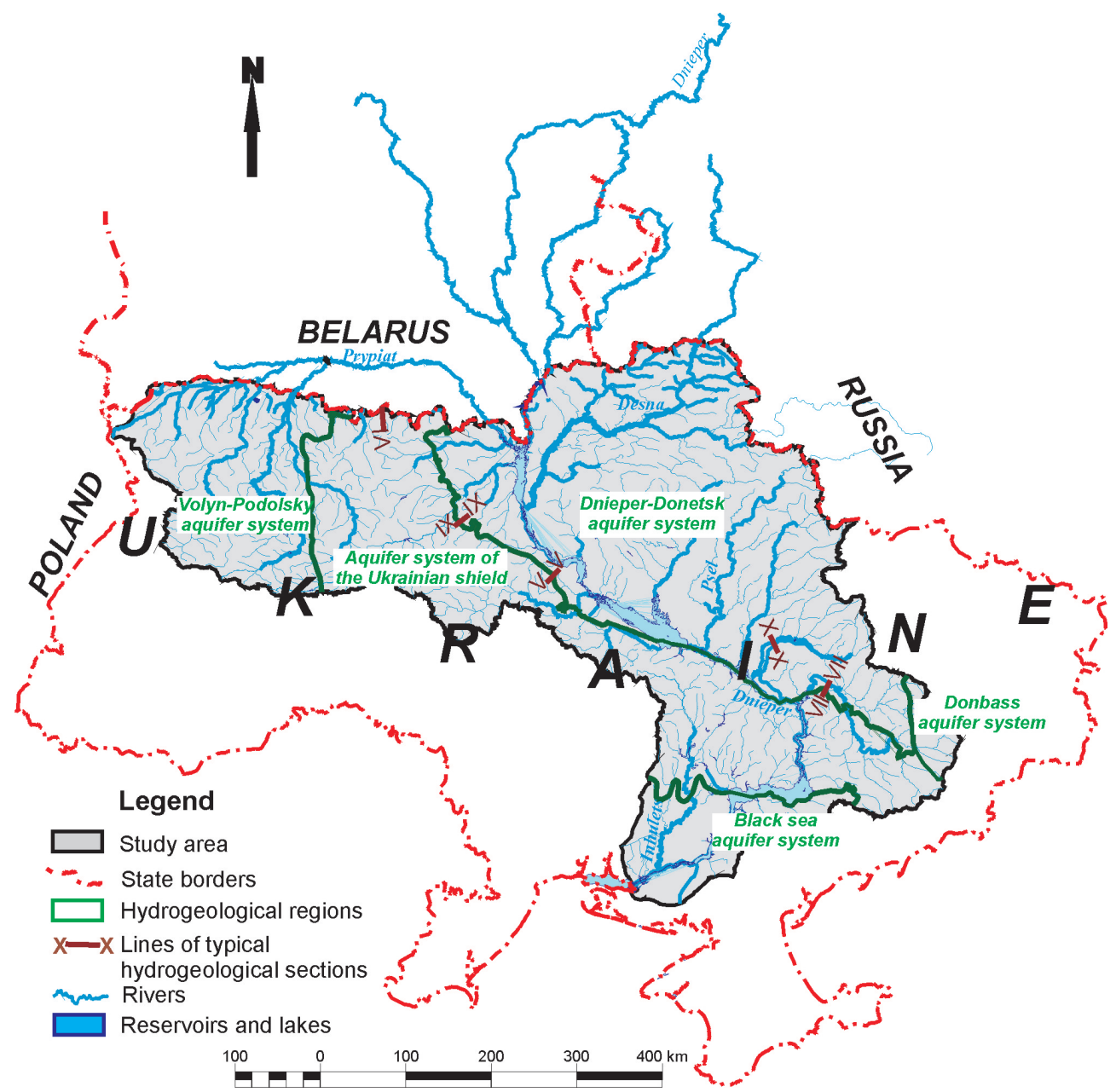

Fig. 1. Studied area of Ukrainian part of the Dnieper River basin

The climatic conditions of the territory are formed under the influence of the northwest movement of air masses created in the North Atlantic anticyclone. Precipitation and air humidity are distributed in a latitudinal direction. Annual precipitation amounts within the certain watersheds decrease as you travel south: from $600-650 \mathrm{~mm}$ in the northwest parts to $460-480 \mathrm{~mm}$ in the southern parts of the Dnieper River basin. Annual precipitation accounts for $16-28 \%$ and $18-23 \%$ of the winter and spring rainfall (correspondently), and $35-52 \%$ of the annual 
precipitation falls in the summer $[3,5]$. Along with the maximum precipitation in the summer months, the total evaporation is observed to increase significantly. This means that the supplying of the ground water with the precipitation is almost absent during the warm season, and the river flow in the low-water period is formed due to the water storages that accumulate from October/November through February.

The geological and geomorphological conditions of the studied territory are quite various. The largest relief structures within the Dnieper River basin are the Dnieper Upland (with its absolute heights that increase from 270 to $321 \mathrm{~m}$ from north to southeast), the Azov Upland (with its highest point of $324 \mathrm{~m}$ ), the Polesian Lowland (with absolute points of 110-150 m), the Black Sea Lowland (50-120 m), Dnieper Lowland (90-170 m), and Poltava Plain (176-202 m). The Donetsk and Podolian Uplands, the watersheds of the basin, are situated to the southeast and southwest of the studied area.

The Ukrainian part of the Dnieper River basin is located within almost all existing geological structures of the plain part of the country. The Ukrainian Crystalline Massif covers the central part of the basin; to the west of which (within the boundaries of the Pripyat River basin), the northern parts of the Volyn-Podolian Plate and Galicia-Volyn Rift are situated. They are filled with Palaeozoic and Cenozoic sedimentary deposits. The Dnieper-Donetsk Rift is located northeast of the Ukrainian Crystalline Massif, within the boundaries of all left-bank tributaries of the Dnieper River. The southwestern slope of the Ukrainian Crystalline Massif and the Black Sea Rift are situated in the southern part of the studied area. The upper part of the geological formations consolidates all structures located in the Dnieper basin, and it is represented by quaternary rocks that include fluvioglacial, wind-laid, and talus deposits.

Pursuant to the hydrogeological zoning of Ukraine, the territory of the Dnieper River basin is situated within the boundaries of three artesian basins: the Volyn-Podolian basin in the west, the Dnieper basin in the northeast, and the Black Sea basin in the south.

In the Dnieper River basin, we can identify the following hydrogeological regions $[5,7,9]$ :

- area of aquifers in the sandy alluvial and fluvioglacial sediments within the right tributaries of the Prypiat River basin;

- area of powerful aquifers in the cavernous and karst limestones of the Cretaceous sediments in the upper part of the basins of the Styr, Horyn, Viliia, Ikva, and Ustia Rivers;

- area of aquifers connected with the fractured zone of crystalline rocks of the Ukrainian Crystalline Massif and the products of their destruction; it covers the basins of the Ubort, Uzh, Teteriv, upper part of the basin of the Irpin, Ros, Ingulets, Tiasmyn, Bazavluk, Mokra Sura, and Vovcha Rivers as well as others; 
- area of aquifers within the Cretaceous, Paleogene, and Quaternary deposits in the region of the lower course of the Uzh, Teteriv, and Irpin Rivers (on the right bank of the Dnieper River) as well as the basins of the Seim, Snov, Sula, Psel, Vorskla, Oril, and Samara Rivers (on the left bank of the Dnieper River);

- area of aquifers in the Neogene deposits, alluvium of the rivers within the boundaries of the Black sea artesian basin in the area of the rivers in the Dnieper River lower course, the Ingulets River basin.

It should be noted that the largest groundwater intakes in Ukraine are situated within the Dnieper River artesian basin, water intakes of the cities of Kiev, Kharkiv, Chernihiv, and water intakes located in the valley of the Siverskyi Donets River, etc. The predicted groundwater resources in the Dnieper River basin in Ukraine are $12.8 \mathrm{~km}^{3}$, only $4.7 \mathrm{~km}^{3}$ of which are not hydraulically connected with the surface waters. The volume of the explored reserves is assessed at $2.6 \mathrm{~km}^{3}$ per year, but the irregularity of their spread reduces the possibility of using them for up to $1.2 \mathrm{~km}^{3}$ [5].

\section{Concept of Hydrogeological Monitoring System Applied in Studied Area on Basis of Geoinformation Approach and Integrated River Basin Principle}

The geoinformation approach [6] provides a systematic usage of the geoinformation analysis required to collect, process, and store information, and it aims to create a permanent GIS-based hydrological model that will permit us to make a quick analysis of the spatially ordered information obtained as a result of the routine observations within any territorial unit.

The geoinformation approach will optimize the following tasks:

- memorization, collection, and systematization of the routine observations and related hydrogeological information obtained as a result of different geological studies;

- analysis and modeling by means of GIS, memorization, and storage of the results;

- presentation of analysis and forecasting results by means of cartographic model creation.

It should be noticed that the mainstreaming of GIS-technologies gives us the possibility to implement the river basin principle for processing the hydrogeological monitoring data of groundwater along with the results of hydrogeological observations. The underflow study system is based on the dynamic characteristics 
of objects pointed out by the principle of the unity of the groundwater flowing from the areas of formation to the place of its main discharge, which is controlled by a single closed groundwater balance [8]. Water exchange basins of the first group, which are characterized by the common or similar trends of regional water exchange, are identified within the hydrogeological structures. The hierarchy of the zoning envisages the selection of the flow-off basins of seas (regions) and main rivers flowing into the seas (provinces). The next level of zoning takes into account the particular features or hydrogeological conditions and similar lateral water exchange trends, which correspond to the water exchange basins of the tributaries of the various main rivers. Basins of the groundwater river flows are consolidated within the single zoning units that are districts or regions of the second level in the territory of which we may point out the sub-districts (regions of the third level). Primarily, the hydrogeological provinces and districts (which have been pointed out under conditions of the water exchange formation in the upper hydrogeological floor) should be considered as the basic territorial units for the state groundwater monitoring system in Ukraine. Thus, a hydrogeological province of the Dnieper River corresponds to the Dnieper River basin. The province includes 25 hydrogeological districts in Ukraine.

In order to create the geodatabase required for the functioning of the state hydrogeological monitoring system within the Ukrainian hydrogeological province of the Dnieper River, we have used the materials issued by Geoinform of Ukraine SSPE, UkrSGRI, and IGS NAS of Ukraine as to the hydrogeological zoning according to the geological structural and water exchange principles, location of the observation hydrogeological and hydrological stations, as well as the results of longterm routine observations. The spatial and attribute information is supplemented with topographic data and brought to a single scale $(1: 100,000)$ and format of the digital map layers in the GIS MapInfo Professional environment (Gauss-Krüger projection, Pulkovo, 1942, zone 6). Results of the routine dynamic observations are stored in the external relational database and can be attached to the spatial objects (hydrological and hydrogeological monitoring stations) using the unique codes of the supervisory stations.

The number of hydrogeological wells in Ukraine have constantly decreased over recent decades (from 1148 points in 2003 to 906 in 2015). The wells of the state hydrogeological monitoring network (where the routine observations over the groundwater levels were carried out during 2009-2014) and operating hydrological stations for surface flow monitoring are plotted on the territorial map (Fig. 2). Nowadays, the hydrological monitoring network for the studied territory is more representational (there are 224 stations) as compared to the observation points' network for groundwater study (there are 206 points).

There has been a strong focus on the surface waters in the framework of international projects $[1,4]$ as to water resource monitoring, especially within cross-border river basins. A significant number of hydrological stations are 
equipped with automatic systems of measurement, and the series of observations over the items of the surface water dynamics are more durable and may be used for updating and restoring the series of the hydrogeological characteristic variability.

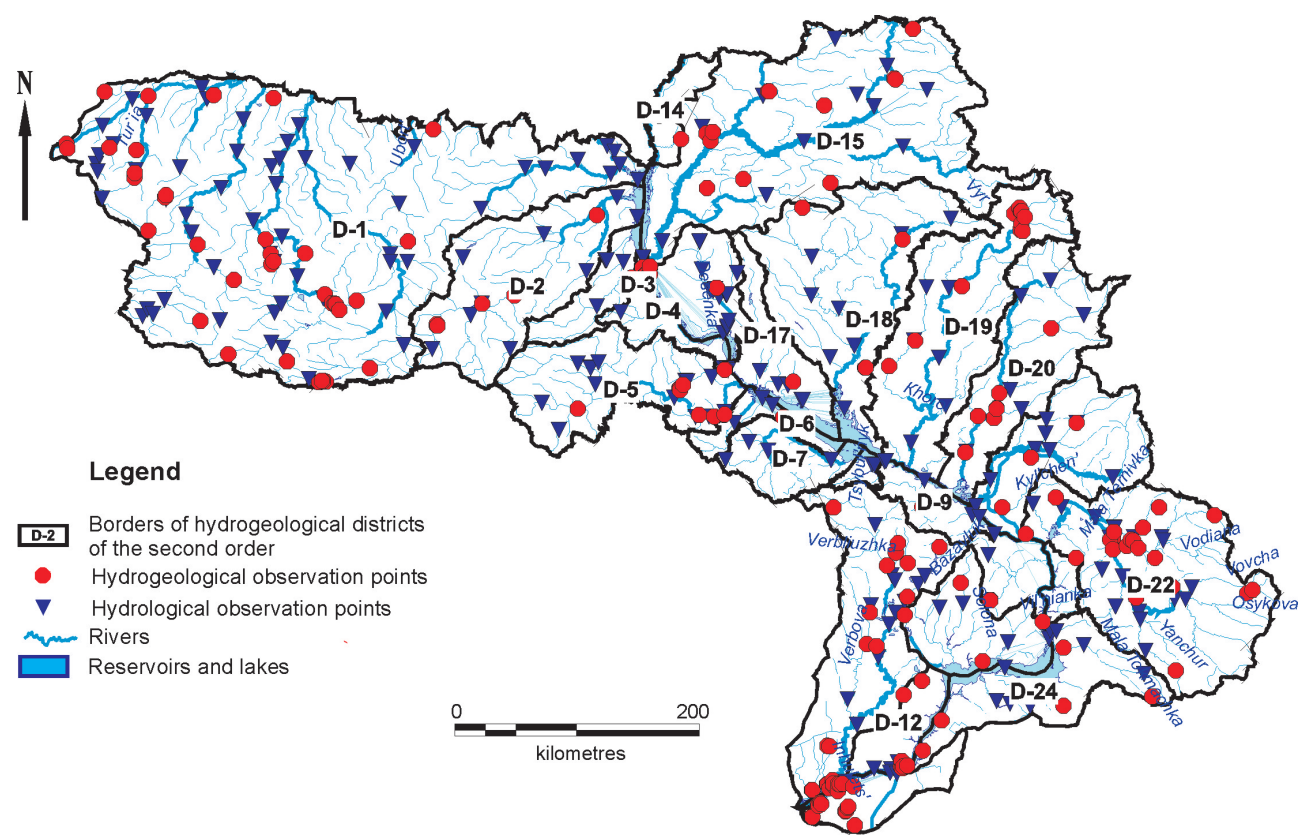

Fig. 2. Location of observation wells and hydrological stations within studied area

Basic tools of GIS MapInfo Professional (including SQL queries and operations and layer superpose operations) allowed us to analyze the location of hydrogeological wells and hydrological stations within the studied territory, and we could assess the network information content of the state groundwater monitoring system for the hydrogeological districts (Tab. 1).

The advisability to conduct the monitoring studies for both surface water and groundwater is also confirmed by the synchronicity of the long-term variability in the average annual surface water discharge and annual average groundwater depth. A synchronicity is observed either as to the actual values of the dynamic items or their long-term trends established for the hydrological stations and hydrogeological wells located in the same hydrogeological district. The similarity in long-term fluctuations of the levels and water discharge may be traced under various climatic and geomorphological conditions for different aquifer types and dynamics, both for natural and technology-changed geological environments (Fig. 3). 
Table 1. Composition of observation network within districts (regions of second level) of hydrogeological province of Dnieper River

\begin{tabular}{|c|c|c|c|c|c|}
\hline 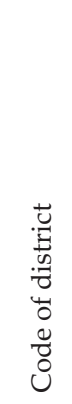 & 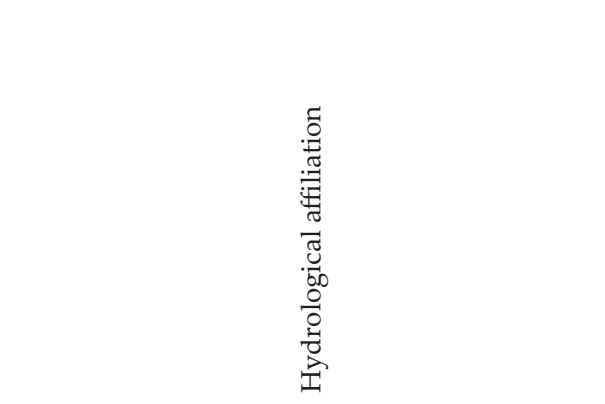 & 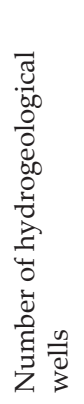 & 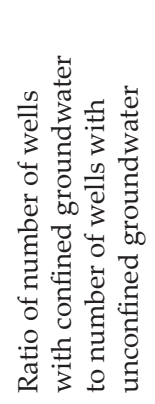 & 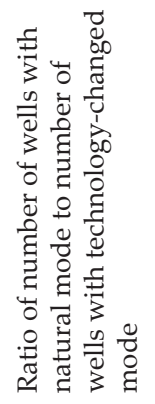 & 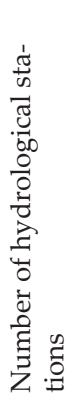 \\
\hline D-1 & Prypiat & 41 & $14 / 27$ & $16 / 25$ & 59 \\
\hline D-2 & Teterev & 7 & $5 / 2$ & $6 / 1$ & 9 \\
\hline D-3 & Irpin & 1 & $1 / 0$ & $1 / 0$ & 5 \\
\hline D-4 & Stuhna - Krasna & 8 & $3 / 5$ & $2 / 6$ & 4 \\
\hline D-5 & Ros & 8 & $5 / 3$ & $7 / 1$ & 16 \\
\hline D-6 & Vilshanka & 1 & $0 / 1$ & $0 / 1$ & 4 \\
\hline D-7 & Tiasmyn - Hnylyi Tashlyk & 0 & $0 / 0$ & $0 / 0$ & 4 \\
\hline D-8 & Tsybulnyk & 0 & $0 / 0$ & $0 / 0$ & 2 \\
\hline D-9 & the right bank of the Kremenchuk reservoir & 1 & $0 / 1$ & $1 / 0$ & 6 \\
\hline D-10 & Mokra Sura & 4 & $4 / 0$ & $4 / 0$ & 1 \\
\hline D-11 & Bazavluk - Tomakivka & 4 & $4 / 0$ & $1 / 3$ & 4 \\
\hline D-12 & the right bank of the Kakhovka reservoir & 5 & $3 / 2$ & $0 / 5$ & 4 \\
\hline D-13 & Inhulets & 21 & $11 / 10$ & $11 / 10$ & 14 \\
\hline D-14 & Dnieper above the Kyiv reservoir & 1 & $0 / 1$ & $0 / 1$ & 0 \\
\hline D-15 & Desna & 15 & $7 / 8$ & $9 / 6$ & 12 \\
\hline D-16 & Trubizh - the left bank of the Kaniv reservoir & 10 & $1 / 9$ & $1 / 9$ & 16 \\
\hline D-17 & $\begin{array}{l}\text { Supiy - Zolotonosha, the left bank of the } \\
\text { Kremenchuk reservoir }\end{array}$ & 1 & $1 / 0$ & $1 / 0$ & 5 \\
\hline D-18 & Sula & 4 & $2 / 2$ & $2 / 2$ & 9 \\
\hline D-19 & Psel & 13 & $4 / 9$ & $2 / 11$ & 7 \\
\hline D-20 & Vorskla & 8 & $3 / 5$ & $2 / 6$ & 6 \\
\hline D-21 & Oril & 3 & $3 / 0$ & $3 / 0$ & 8 \\
\hline D-22 & Samara & 24 & $14 / 10$ & $16 / 8$ & 19 \\
\hline D-23 & the left bank of the Dnieper reservoir & 0 & $0 / 0$ & $0 / 0$ & 0 \\
\hline D-24 & $\begin{array}{l}\text { the left bank of the Kakhovka reservoir, Kinska, } \\
\text { Bilozerka }\end{array}$ & 9 & $5 / 4$ & $3 / 6$ & 9 \\
\hline D-25 & Black Sea Coast & 17 & $9 / 8$ & $6 / 11$ & 1 \\
\hline
\end{tabular}




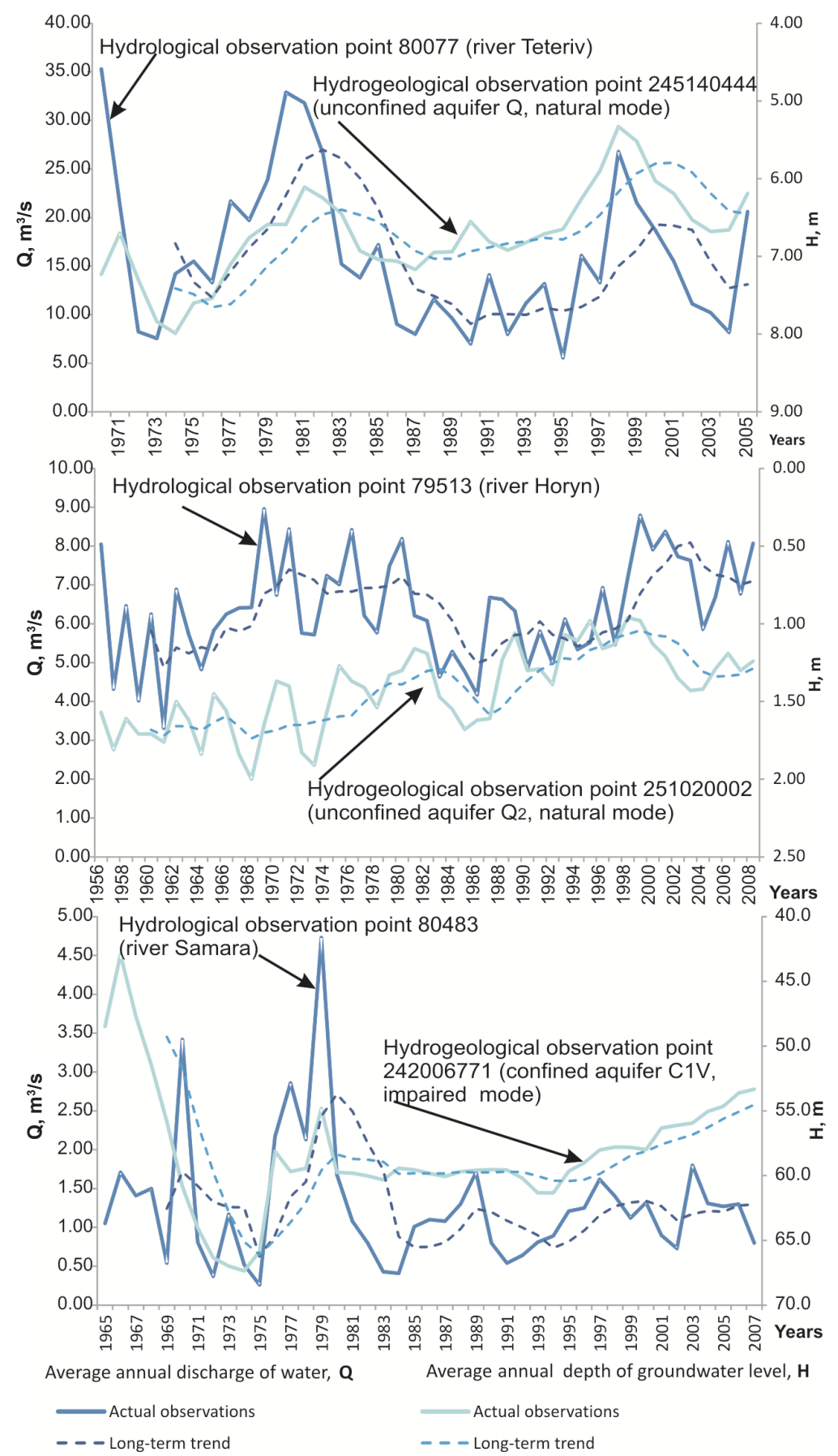

Fig. 3. Examples of comparisons of long-term hydrological and hydrogeological parameter variability for different districts of hydrogeological province of the Dnieper River 


\section{Analysis of Observation Network for Groundwater Dynamic Monitoring within Hydrogeological Province of Dnieper River}

The overlay-analysis and thematic-mapping tools in the MapInfo Professional environment have been used to visualize the informative content of the state network within the hydrogeological districts. A rank cartogram (Fig. 4) displays the availability of the observation points for groundwater dynamic monitoring within the hydrogeological territory and confirms its insufficient quantity, uneven distribution within the studied area, and (thus) the lack of information about groundwater conditions for the individual districts.

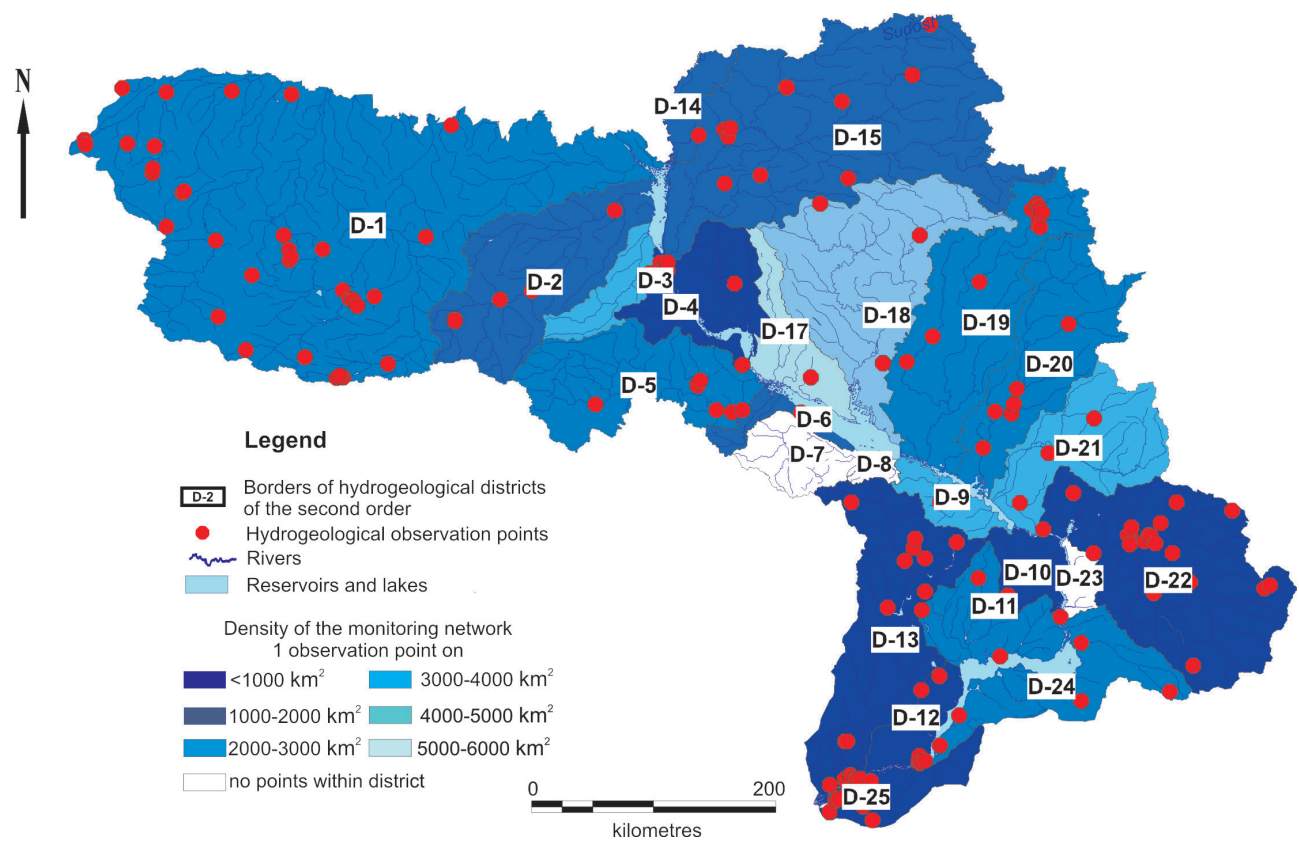

Fig. 4. Rank cartogram of density of state hydrogeological monitoring network within hydrogeological districts

We may consider the water exchange basins of the upper courses of the Dnieper River (the Supiy-Zolotonosha and Sula Rivers) as insufficiently equipped observation wells. For these districts as well as for the water exchange basins of the Tiasmyn River, Tsybulnik River and left bank of the Dnieper reservoir (where there are no existing hydrogeological points), the geodatabase for the groundwater dynamics should be supplemented with cartographic layers of climate zoning and location of weather stations as well as by the results of observation over the variability of the meteorological characteristics. 


\section{Conclusions}

The system of state underground water monitoring in Ukraine is in poor condition now, which results in a loss of data as to the continuous long-term dynamic observations over the qualitative and quantitative hydrogeological characteristics and reduces the reliability of the estimates and forecasts concerning the groundwater conditions and development of adverse processes; therefore, the prevention of adverse changes in the geological environment becomes impossible.

Under conditions of limited funding, is very important to develop an effective strategy for reforming the hydrogeological monitoring system, taking into account international experience and based on modern geoinformation technologies. A single geodatabase will allow us to preserve the existing results of hydrogeological investigations, provide the integration of heterogeneous data and their operational analysis, and provide the possibility of optimizing the observing network and effective international cooperation in monitoring of the transnational water objects.

\section{References}

[1] Berezko O., Vasneva O. Groundwater monitoring in Belarus: implication and future prospects. [in:] Nałęcz T. (eds.), Transboundary Aquifers in the Eastern Borders of The European Union, NATO Science for Peace and Security Series C: Environmental Security, Springer Science+Business Media, Dordrecht 2012, pp. 115-120.

[2] Directive 2000/60/EC of the European Parliament and of the Council of 23 October 2000 establishing a framework for Community action in the field of water policy [official website]. [on-line:] http://eur-lex.europa.eu/resource.html ?uri=cellar:5c835afb-2ec6-4577-bdf8-756d3d694eeb.0004.02/DOC_1\&format=PDF [access: 09.03.2017].

[3] Halushchenko O.: Rozpodil poliv kilkosti atmosfernykh opadiv na richkovykh vodozborakh baseinu Dnipra [Галущенко О.: Розподіл полів кількості атмосферних опадів на річкових водозборах басейну Дніпра]. Visnyk Kyivskoho universytetu. Seria Heohrafiia, no. 4, 1995, pp. 109-119.

[4] Identification, characterization and delineation of groundwater bodies in Moldova and Ukraine in the river basins of Dnieper (Ukraine-Belarus) and Prut (UkraineMoldova) [official website]. [on-line:] http://www.blacksea-riverbasins.net [access: 04.02.2017].

[5] Khilchevskyy V., Romas I., Romas M., Hrebin V., Shevchuk I., Chunarov O.: Hidroloho-hidrokhimichna kharakterystyka minimalnoho stoku richok baseinu Dnipra [Хільчевський В., Ромась I., Ромась М., Гребінь В., Шевчук I., Чунарьов О.: Гідролого-гідрохімічна характеристика мінімального стоку річок басейну, Дніпра]. Nika-Centr, Kyiv 2007. 
[6] Koshliakov O.: Monitorynh hidroheodynamichnoi skladovoi heolohichnoho seredovyshcha urbanizovanykh terytorii (na osnovi GIS). [Кошляков О.: Моніторинг гідрогеодиналічної складової геологіного середовища урбанізованих територій (на основі ГІС)]. Vernadsky National Library of Ukraine, Kyiv 2011.

[7] Ruban S., Shynkarevskyi M.: Hidroheolohichni otsinky ta prohnozy rezhymu pidzemnykh vod Ukrainy [Рубан С., Шинкаревський М.: Гідрогеологічні оцінки та прогнози режиму підземних вод Украйни]. UkrDHRI, Kyiv 2005.

[8] Shestopalov V., Blinov P., Lyutyi H.: Suchasni pryntsypy hidroheolohichnoho raionuvannia / [Шестопалов В., Блінов П., Аютий Г.: Сучасні принц̧ипи гідрогеологічного районування]. Zbirnyk naukovykh prats UkrDHRI, no. 3-4, 2010, pp. 147-157.

[9] Shestopalov V., Drobnohod N., Ljal'ko V.: Vodoobmen v gidrogeologicheskih strukturah Ukrainy. Vodoobmen v estestvennyh uslovijah [Шестопалов В., Дробноход Н., Аялько В.: Водообмен в гидрогеологических структурах Украины. Водообмен в естественных условиях]. Naukova dumka, Kyiv 1989.

[10] Shestopalov V., Lyuta N.: Stan i shlyakhy reformuvannya derzhavnoyi systemy monitorynhu pidzemnykh vod z urakhuvannyam mizhnarodnoho dosvidu ta vymoh vodnoyi ramkovoyi dyrektyvy Yevropeys'koho Soyuzu [Шестопалов В., Пюта Н.: Стан і шляхи реформування державної системи моніторингу підземних вод з урахуванням міжнародного досвіду та вимог водної рамкової директиви Європейського Союзу]. Mineral'ni resursy Ukrayiny, no. 2, 2016, pp. 3-4.

\section{Ocena stanu sieci obserwacyjnej oraz znajomości reżimu wód podziemnych prowincji hydrogeologicznej rzeki Dniepr na terenie Ukrainy}

Streszczenie: W celu ponownego uruchomienia państwowej sieci hydrogeologicznej i dostosowania jej do standardów europejskich w możliwie najkrótszym terminie realizowane będą następujące zadania priorytetowe: inwentaryzacja stacji obserwacyjnych, ocena ich reprezentatywności, opracowanie koncepcji reformy systemu monitoringu oraz utworzenie jednej bazy danych z wykorzystaniem technologii GIS. Realizując powyższe zadania, przeprowadzono analizy geoinformatyczne dotyczące lokalizacji stacji monitorowania wód gruntowych w obrębie największej struktury hydrogeologicznej na Ukrainie (czyli zlewni wymiany wód Dniepru). W trakcie badań została utworzona baza danych, która obejmuje cyfrowe warstwy kartograficzne bazy topograficznej, ukształtowanie hydrogeologiczne pod strukturą geologiczna, zasady wymiany wód oraz 
stanowiska monitorowania wód powierzchniowych i podziemnych różnych warstw wodonośnych.

Uzyskane wyniki stanowią podstawę do opracowania koncepcji i wprowadzenia systemu monitoringu hydrogeologicznego na Ukrainie w oparciu o podejście geoinformacyjne i zintegrowane zarządzanie zasobami wodnymi w dorzeczach.

Słowa

kluczowe: monitoring hydrogeologiczny, model dorzecza, podejście geoinformacyjne, punkty obserwacyjne. 